\title{
Tertiary Level Students' Attitudes Toward Job Destination: An Empirical Study on Bangladeshi Students
}

\author{
Md. Ashraful Islam Khan ${ }^{1 *}$, Md. Abid Hassan Mojkury² and Prosannajid Sarkar \\ ${ }^{1}$ Professor, Department of Population Science and Human Resource Development, University of Rajshahi, Bangladesh \\ ${ }^{2}$ Post-Graduate Researcher, Department of Population Science and Human Resource Development, University of \\ Rajshahi, Bangladesh \\ ${ }^{3}$ Senior Researcher, Dr. Wazed Research and Training Institute, Begum Rokeya University, Rangpur, Bangladesh \\ "Corresponding author: khan75ru@ru.ac.bd
}

Received: 14 Mar., $2021 \quad$ Revised: 12 May, $2021 \quad$ Accepted: 05 Jun., 2021

\begin{abstract}
Tertiary level education is the key to modern development of any nation and the outcome-based curricula is the pivotal to the standard of the tertiary level education system. The tertiary level educational institutes play the crucial role to change the society and development at any time and horizon. In Bangladesh, several quality development and assurance institution are running to promote the standard of tertiary level education. We know that the graduates will face very competitive job market after their graduation, therefore, ensuring the superior quality and standard of the graduates need to be very significant for better employability. This study is an opinion survey among tertiary level students of different universities that assesses their learning and goal-setting attitude for job achievement. The opinion of 750 tertiary level students is collected from different universities of Bangladesh purposively through a well-structured questionnaire. We observe almost similar job target attitude of students from different backgrounds. The socio-economic and education related factors play very significant role for their target-setting attitude.
\end{abstract}

Keywords: Tertiary Education, Learning Goals, Job Destination, Goal-Setting, Learning Attitude

Attitude is a moderately forceful emotion that prepares or influences an individual to respond consistently in a favorable or unfavorable manner when confront with a particular object (see, e.g., Anderson, 1985; Chambers and Pittman, 1986; Lord, 1997). It is recognized that the higher education system is highly correlated with overall development, of the society. Development of higher education plays the key role to produce adequately trained manpower. The efficiency of higher education system positively affects on students learning attitude. Different quality assurance agencies and accreditation councils are working to enhance the efficiency of education system and improve students' learning attitude. E-learning 
(see, e.g., Maltz et al. 2005; Wagner et al. 2008; Zhang et al. 2006) and m-learning (see, e.g., Naismith et al. 2004; Yuen \& Yuen 2008, Clark \& Mayer, 2008; Horton, 2006; Peters, 2007) came out to expand the learning environment. $\mathrm{Tt}$ is well recognized that the effectiveness of higher education institutions, education policy and programs contribute to both national and international development. Students motivation towards learning also depends on their achievement of learning goals (see, e.g., Tomlinson 2012; Clements \& Kamau, 2018).

\section{Objectives of the study}

The aim of this study is to assess tertiary level students' attitude toward their learning and goals-setting, and identify determinants responsible for their attitude.

\section{Literature Review}

Human capital is widely viewed as a strategic resource. Since its inception, resource-based theory asserted that the heterogeneity of strategic resources such as human capital explains performance differences among firms (Ketchen, Jr. et al. 2017). Theory at both the micro and macro level predicts that investments in superior human capital generate better firm-level performance (Crook et al. 2011). However, learning is a vital aspect of all human resource development efforts (see, Bingham \& Jeary, 2007 and Daley, et al. 2010) and human capital formation. The goal of learning is simply to change the behavior, knowledge or attitude. Student attitudes towards learning determine their ability and willingness to learn. If negative attitudes are not altered, a student is unlikely to continue his education beyond what is required. However, Locke and Latham (1990) proposed the goal setting theory and suggested that people perform better when they have 'high goals' that are specific, challenging and achievable. Locke and Latham (2013) argued over challenging goals because of producing a high level of motivation and requires new strategies to enhance effort or performance. Clements \& Kamau (2018) pointed out that there have been over 1000 studies supporting the goal-setting framework but little research is available on testing its application in student populations (see also, e.g. Latham and Locke 2007; Seijts and Latham 2011). They also mentioned that the university students working towards their future employability have several competing demands including class attendance, course works, examinations, part-time or full-time jobs and this presents a demand conflict. They applied Demerouti et al. (2001) Job Demands-Resources model to observe students demand conflict. Tymon (2013) conducted focus group discussions and observed that the final year students had much higher concept of employability compare to first and second year students in tertiary level education. Klein et al. (1999) meta-analytic review demonstrated that goal difficulty moderates the relationship between goal commitment and performance. However, Biggs and Tang (2011) and Entwistle (2007) recorded a prolific growth in research on student learning focusing on the psychology of individual differences and the characteristics associated with deep and surface approaches to learning. Biggs and Tang (2011) identified that the challenge for the teacher was to reduce the gap between deep and surface learners regarding their engagement with the teaching and learning process.

The impact of the contextual change pivots around two outcomes. First, a large body of literature (e.g., Gruber et al. 2010) views that the students increasingly perceive themselves as customers. Second, public funding cuts derive from the neo-conservative belief that education has personal benefits for which one should have to pay, as for any other goods (Biggs \& Tang, 2011). "Mc Donaldisation" of higher 
education (Deem et al. 2007) has established the primacy of the vocational and professional orientation with a discernible trend away from what used to be a primarily academic focus in higher education until about two decades ago. Star and Hammer (2008) challenged the "dichotomy that conceives of a fundamental disjuncture between the idea of universities as institutions of vocational education and the more traditional conception of universities as key institutions in the formation of reflective practitioners, social critics and good citizens".

\section{Data Base and Methodology}

There are 750 data had been collected purposively through a well-structured questionnaire. The questionnaire was developed on the basis of study objectives. All the questions were closed ended except the quantitative questions. The five-point Likert scale was used to measure the attitudes and opinions. Descriptive statistics and the qualitative technique, Chi-square test, were used to assess the tertiary level students' attitude and opinion towards their learning goals, and the effects of their socio-economic status and educational standard on their learning goals.

We collected data from students of different public and private tertiary educational institutes including public universities, national university (this is also a public university but it has a wide range of country wide coverage and sometimes differ from the mainstream public universities), medical university, university of engineering and technology and few private universities of Bangladesh by direct interview method. The collected data exhibit the following characteristics:

Table 1: Demographic and economic status

\begin{tabular}{llll}
\hline & Age & Family Income & Family expenditure \\
\hline Minimum & 18.00 & 1500.00 & 1200.00 \\
Maximum & 27.00 & 500000.00 & 400000.00 \\
Mean & 22.39 & 37251.33 & 28713.05 \\
Std. Deviation & 0.06 & 1611.80 & 1144.98 \\
Skewness & 2.41 & $1.948 \mathrm{E} 9$ & $9.832 \mathrm{E} 8$ \\
Kurtosis & -0.13 & 5.967 & 6.402 \\
\hline
\end{tabular}

The average age of the respondents observed 22.39 years with standard deviation 0.06 . Skewness is far from zero (2.41) and kurtosis is -0.129 which is less than 3 . Average family income and expenditure observed 37,251.00 TK and 28,713.00 respectively per month with comparatively large standard deviations 1611.80 and 1144.98 respectively. The skewness and kurtosis are also far from zero and 3 respectively.

Table 2: Socio-economic characteristics

\begin{tabular}{llll}
\hline Characteristics & & Frequency & Percentage \\
\hline \multirow{2}{*}{ Sex } & Female & 450 & 40.0 \\
& Male & 350 & 60.0 \\
\multirow{2}{*}{ Age group } & 22 years or bellow & 378 & 50.4 \\
& Above 22 & 372 & 49.6 \\
\hline \multirow{2}{*}{ Family Types } & Nuclear & 607 & 80.9 \\
& Joint & 143 & 19.1 \\
\hline
\end{tabular}




\begin{tabular}{llll}
\hline \multirow{2}{*}{ Monthly Income } & Less than or equal to average & 499 & 66.5 \\
& Above average & 251 & 33.5 \\
\hline \multirow{2}{*}{ Monthly Expenditure } & Less than or equal to average & 482 & 64.3 \\
& Above average & 268 & 35.7 \\
\hline \multirow{5}{*}{ Place of SSC institution } & Village & 236 & 31.5 \\
& Union Sadar & 98 & 13.1 \\
& Upozilla/Pourosova & 186 & 24.8 \\
& District & 119 & 15.9 \\
& City Corporation & 111 & 14.8 \\
\hline \multirow{3}{*}{ Place of HSC institution } & Village & 72 & 9.6 \\
& Union Sadar & 46 & 6.1 \\
& Upozilla/Pourosova & 177 & 23.6 \\
& District & 227 & 30.3 \\
& City Corporation & 227 & 30.3 \\
\hline \multirow{5}{*}{ Current institution } & Public University & 486 & 64.8 \\
& Engineering & 125 & 16.7 \\
& Medical University & 33 & 4.4 \\
& National University & 55 & 7.3 \\
& Private University & 51 & 6.8 \\
\hline
\end{tabular}

From Table 2 we observe $60 \%$ of our respondents are male and rest $40 \%$ female. We grouped respondents on the basis of their average age and monthly income-expenditure for further analysis. The age structure seems normal. $50.4 \%$ of the respondents are of average and below average group and rest $49.6 \%$ are above average age where average age observed 22.39 years. Majority of the respondents are belonging to the average and below average income level (66.5\%). Similar status observed for the expenditure (64.3\% in average and below average group).

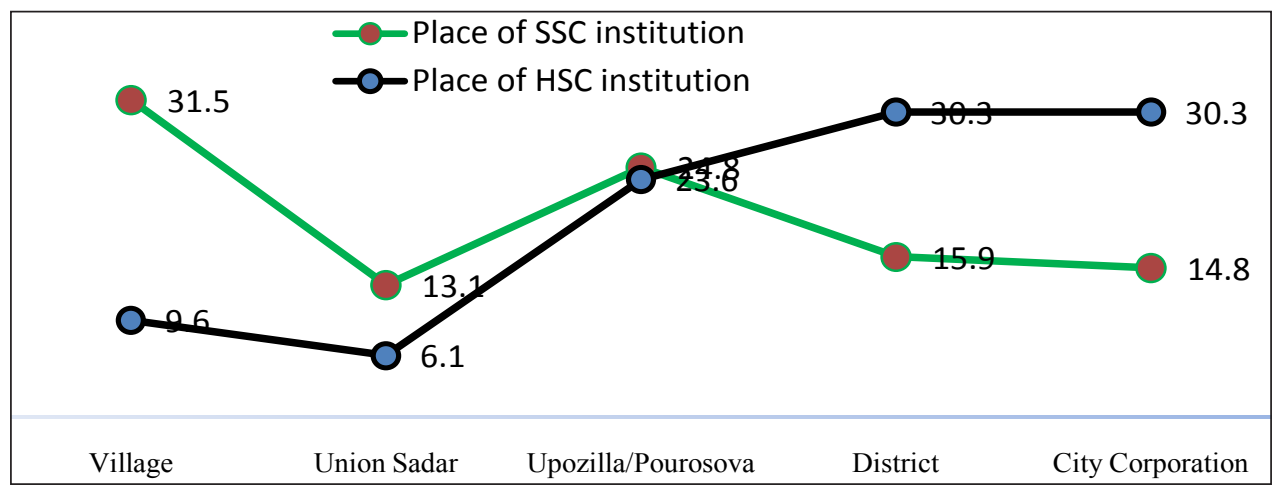

Fig. 1: Trends of SSC and HSC level Educational Institutes

Most of the respondents belong to the nuclear family (80.9\%) and only $19.1 \%$ of them belong to extended and/or joint family.

When SSC and HSC level educational institutes considered, we observe a clear educational migration among students. A large number of students move from rural to urban for higher education. In SSC level, there were $31.5 \%$ students passed from village and 13.1 from union sadar, that is, $44.6 \%$ students used 
to study in rural area. This structure changed at HSC level. Only $15.7 \%(9.6 \%$ at village $+6.1 \%$ at union Sadar) students studied in the rural area. Fig. 1 clarifies this trend.

However, the structure of respondents' current institutions shows 64.8\% from Public Universities followed by Engineering Universities, Medical universities, National University and Private Universities. Fig. 2 shows the outline.

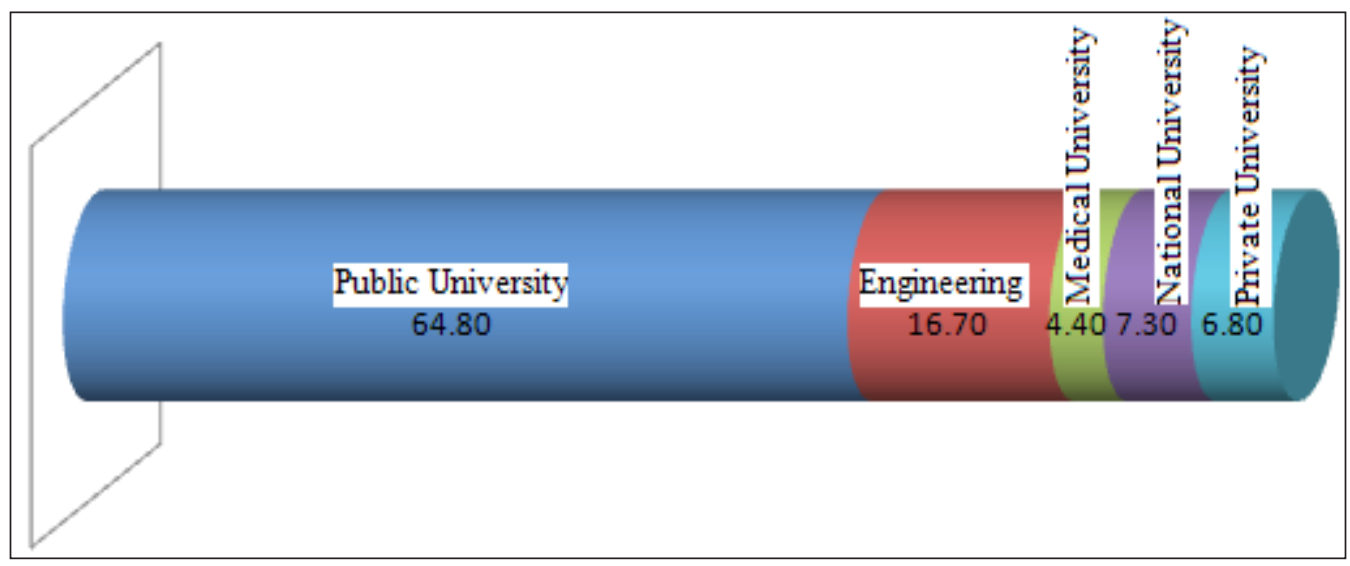

Fig. 2: Students' distribution according to institutions

\section{RESULTS AND DISCUSSION}

\section{Learning Goals}

Graduates face very competitive labour market and lots of difficulties to manage job after their graduation (see, e.g., Smith 2010; Tomlinson 2012; Helyer and Lee 2014). Tymon (2013) mentioned that the undergraduate students often lack of understanding regarding the job market and its importance until their final year of study. We seldom observe job survey conducts in the least developed and developing countries. Therefore, the institutional effectiveness may not be measureable. The institutional effectiveness may be measured in a number of areas, such as graduation, retention, job placement, number and effectiveness of student services, management and administrative structure, physical infrastructure; while measurement in these areas is critical.

Students desire to improve skills, increase knowledge, or change attitudes to achieve their learning goals. Clements and Kamau (2018) advocated that the goal-setting theory can explain why some students do better than others at setting challenging career goals and why some types of motivation are better than others at achieving outcomes such as engaging in practical behaviors that contribute to future employability. In this section, we aim to asses tertiary level students attitude towards learning goals and how socioeconomic and education related determinants help them achieving their learning goals. A 5-point Likert scale (ranging from $1=$ strongly disagree to $5=$ strongly agree) used to measure students' opinions and attitudes. 
Table 3 bellow focus on the job destination of our respondents and Fig. 3 clarifies the pattern.

Table 3: Job destination and extra curricula activities

\begin{tabular}{llll}
\hline \multirow{2}{*}{ Job Destination } & \multicolumn{3}{c}{ Percent } \\
\cline { 2 - 4 } & Male & Female & Overall \\
\hline Government & 59.33 & 70.00 & 63.6 \\
Private & 10.00 & 6.67 & 8.7 \\
Business & 5.56 & 1.00 & 3.7 \\
Teaching & 6.89 & 14.67 & 10.0 \\
Jon in Abroad & 11.11 & 5.00 & 8.7 \\
Others & 7.11 & 2.67 & 5.3 \\
\hline
\end{tabular}

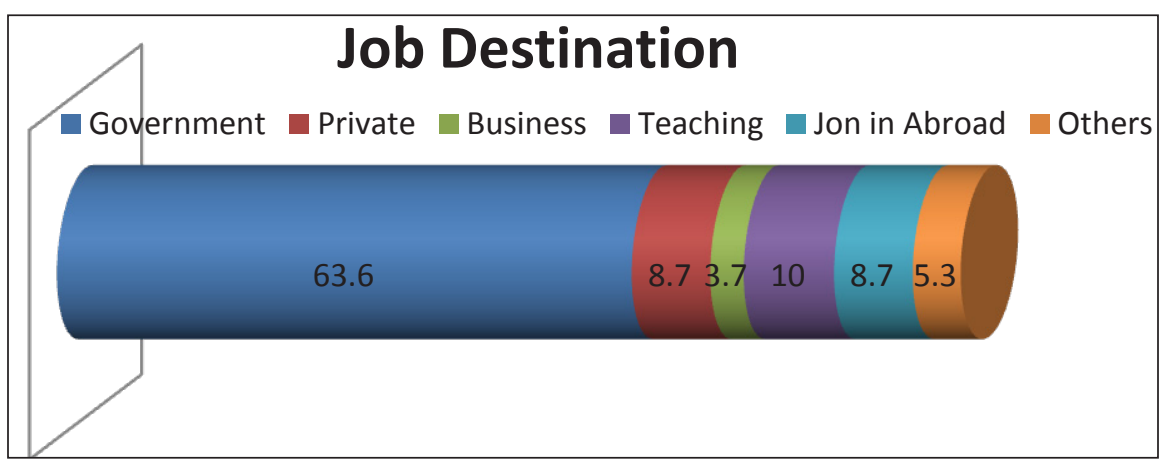

Fig. 3: Job destination of the respondents

We observe most of the respondent's job target is in government sector (63.6\%) followed by teaching. Private sector is not yet being targeted by our respondents as well as job in abroad. Only $8.7 \%$ respondents aimed to have job in private sectors and another $8.7 \%$ wished to have job in abroad. Almost similar picture observed when we consider gender wise job destination. Female respondents have more fascination on government job and teaching compared to male respondents. On the other hand, male respondents are comparatively more interested to have private job and job in abroad. The following Fig. 4 clarifying this phenomenon.

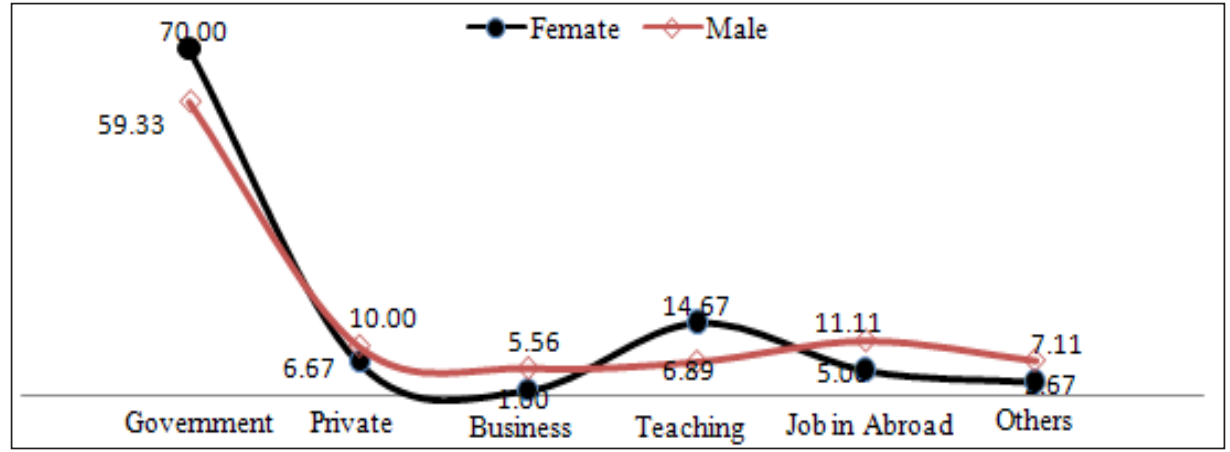

Fig. 4: Gender wise job destination of the respondents 
When we observed respondents, opinion based on other socio-economic (family type, monthly income and expenditure) and education related factors (place of SSC and HSC level educational institutes, types of current educational institutes, faculty under study, curricula and earned GPA) along with respondents' age regarding job target, we found almost similar trends as observed for gender. The figures bellow clarifies this statement.

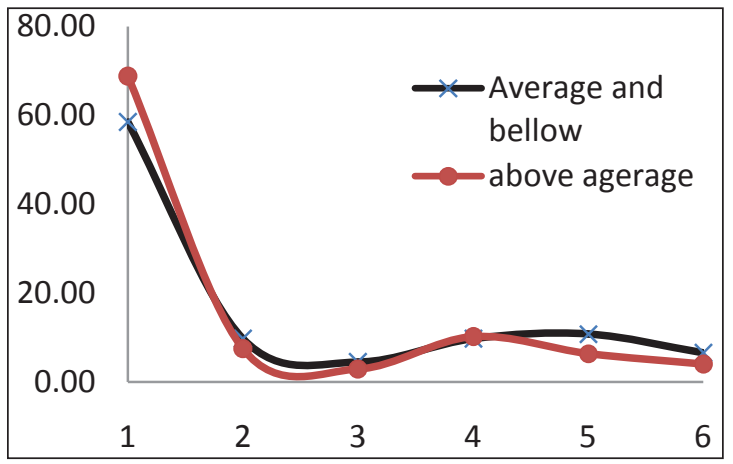

Fig. 5: Age wise job destination

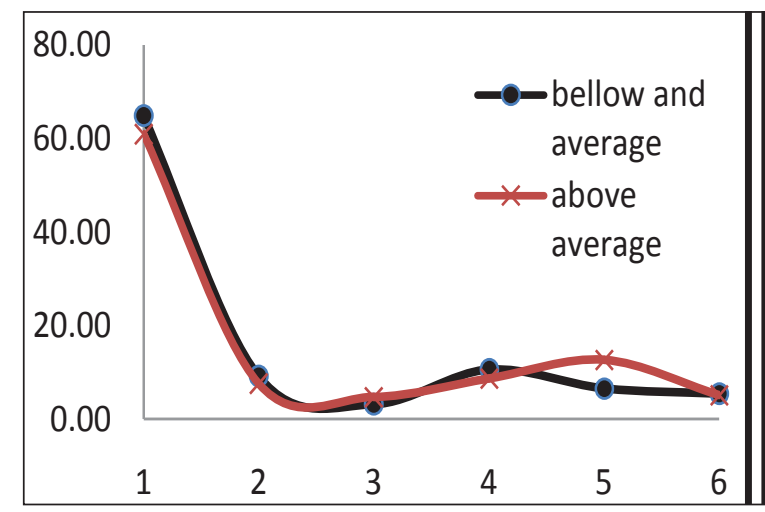

Fig. 7: Income wise job destination

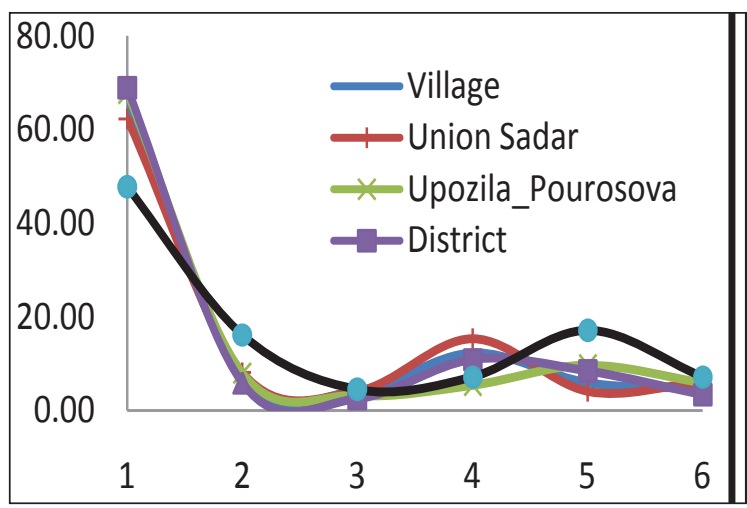

Fig. 9: SSC level wise job destination

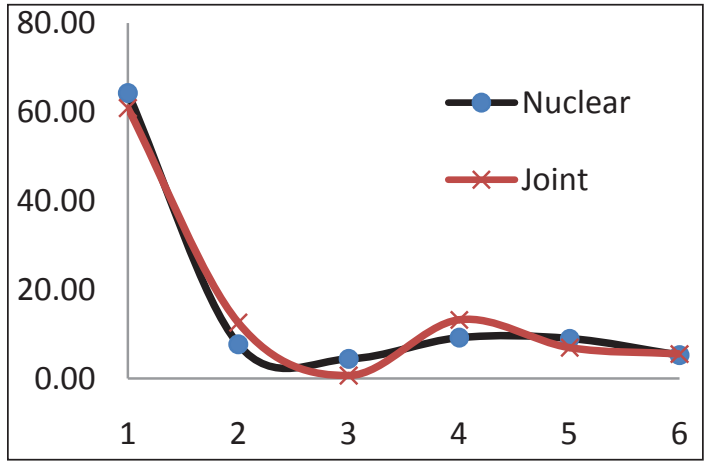

Fig. 6: Family type wise job destination

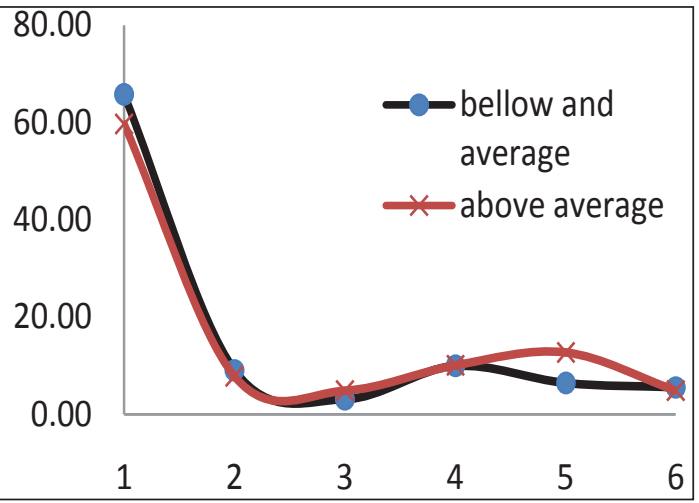

Fig. 8: Expenditure wise job destination

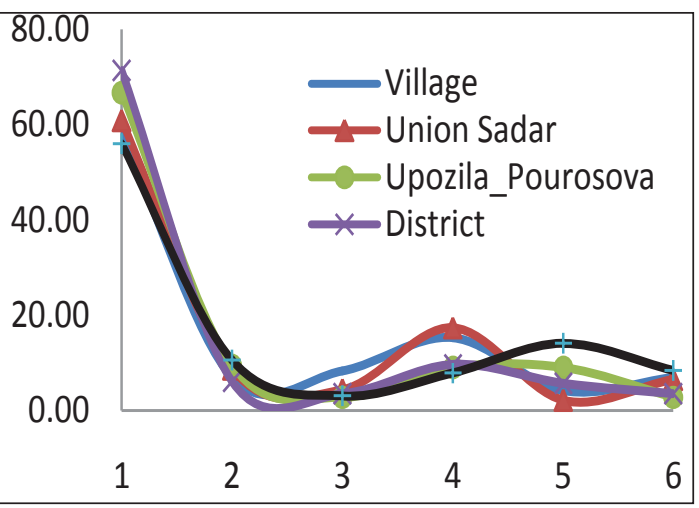

Fig. 10: HSC level wise job destination 


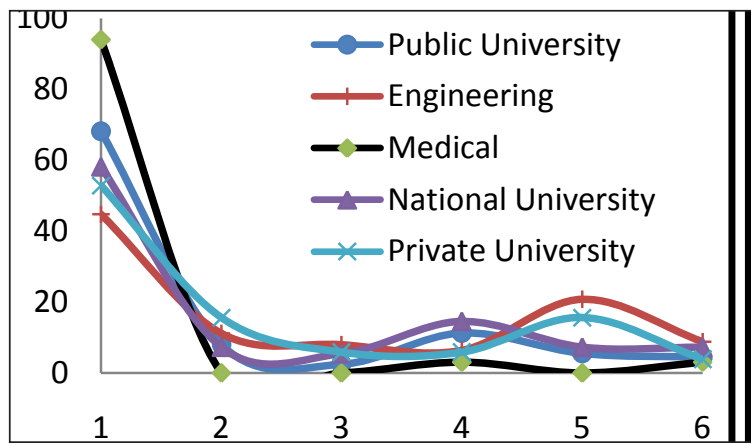

Fig. 11: Instruction wise job destination

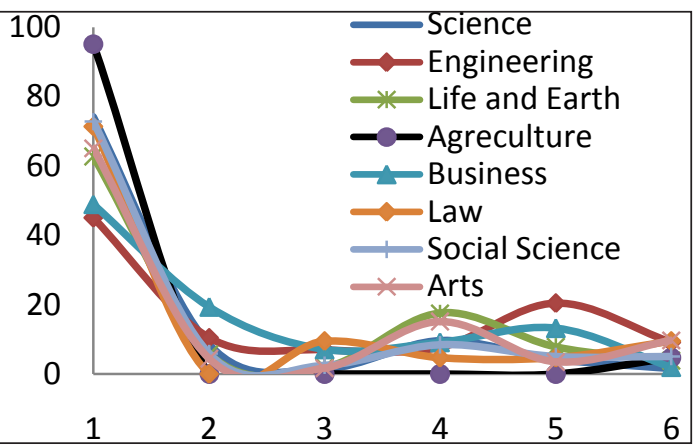

Fig. 12: Faculty wise job destination

We shall now focus on different socio-economic and education related factor responsible for respondents' opinions regarding job target. We shall observe the Chi-square test results for significance of inter association of different attributes considered in this study with respondents' job target.

Table 5: Socio-economic and education

\begin{tabular}{|c|c|c|}
\hline \multicolumn{2}{|l|}{ Attributes } & \multirow{2}{*}{$\begin{array}{l}\boldsymbol{x}^{2} \text { and } \boldsymbol{p} \text { - values } \\
x^{2}=12.01\end{array}$} \\
\hline \multirow{22}{*}{ Job Destination } & \multirow{2}{*}{ Age group } & \\
\hline & & $p=\mathbf{0 . 0 3 5}$ \\
\hline & \multirow{2}{*}{ Gender } & $x^{2}=40.85$ \\
\hline & & $p=\mathbf{0 . 0 0 0}$ \\
\hline & \multirow{2}{*}{ Family Types } & $x^{2}=10.21$ \\
\hline & & $p=0.070$ \\
\hline & \multirow{2}{*}{ Monthly Income } & $x^{2}=9.89$ \\
\hline & & $p=0.078$ \\
\hline & \multirow{2}{*}{ Monthly Expenditure } & $x^{2}=10.68$ \\
\hline & & $p=0.058$ \\
\hline & \multirow{2}{*}{ Place SSC level education } & $x^{2}=40.38$ \\
\hline & & $p=\mathbf{0 . 0 0 4}$ \\
\hline & \multirow{2}{*}{ Place HSC level education } & $x^{2}=50.72$ \\
\hline & & $p=\mathbf{0 . 0 0 2}$ \\
\hline & \multirow{2}{*}{ Current Institute } & $x^{2}=74.88$ \\
\hline & & $p=\mathbf{0 . 0 0 0}$ \\
\hline & \multirow{2}{*}{ Current Faculty } & $x^{2}=117.1$ \\
\hline & & $p=\mathbf{0 . 0 0 0}$ \\
\hline & \multirow{2}{*}{ Curricula to job achievement } & $x^{2}=50.23$ \\
\hline & & $p=\mathbf{0 . 0 0 0}$ \\
\hline & \multirow{2}{*}{ Earned GPA to job achievement } & $x^{2}=22.85$ \\
\hline & & $p=0.586$ \\
\hline
\end{tabular}

We observe from Table 5 that respondents age and gender is highly associated with their job targets. The family type has also significant impact on their job target $(p=0.07)$. The economic status has also 
a significant effect on respondents job target, for monthly income the $p$-value is 0.078 while for monthly expenditure the $p$-value is 0.058 .

Almost all the education related factors considered in this study (the geographical place of SSC level educational institutes, geographical place of HSC level educational institutes, the types of tertiary level educational institutes, the faculty of tertiary level education and the curricula of tertiary level education) have highly significant effect on respondents job target. Very strange result observed for the earned GPA of the respondents to achieve their targeted job, the -value observed 0.586 .

\section{CONCLUSION}

This is an empirical study to observe the students' attitude towards their learning goals. Clements \& Kamau (2018) encourage academics and university staff working on student's employability through three types of interventions:

1. Train students about goal-setting theory,

2. Train students about optimum career behaviours such as career planning, building career networks, career consultation and career skills-building so that students are aware of the different strategies and

3. Facilitate proactive career behaviours as a formal part of a student's degree. We focused mainly on tertiary level students' goal-setting trend and the determinants responsible for their goal-setting.

As we mentioned earlier, the graduates will face a very competitive job market after their graduation, therefore, perfect goal-setting is very crucial to achieve their targeted job. We get various evidence from literature that the awareness concerning career management and job placement enable students to develop skill that will enhance their future employment opportunities (see, e.g., Komarraju, Swanson, and Nadler 2014; Taylor and Hooley 2014; Tymon 2013; Thune and Støren 2015; Wilton 2012; Freudenberg, Cameron, and Brimble 2011; Smith and Worsfold 2015; Mason, Williams, and Cranmer 2009). We set a goal to make tertiary level students aware about their learning outcomes and job destination during the data collection process by asking relevant questions. We observed lot of unconsciousness of the tertiary level students regarding their job target, their curricula and earned GPA. We hope that future empirical research finding will help tertiary level students to became significantly aware regarding their learning outcome and job target behaviours. The academics finding and students awareness collectively produce better employability atmosphere.

\section{REFERENCES}

1. Anderson, L.W. 1985. Attitudes and Their Measurement, the international encyclopedia of educational research and studies. New York: Longman green and co.

2. Andrew James Clements \& Caroline Kamau. 2018. "Understanding students' motivation towards proactive career behaviours through goal-setting theory and the job demands-resources model", Studies in Higher Education, 43(12): 2279-2293.

3. Biggs, J. and Tang, C. 2011. Teaching for Quality Learning at University. Buckingham, U.K. \& Philadelphia, Pa.: Society for Research into Higher Education \& Open University Press ( $4^{\text {th }}$ Edition).

4. Bingham, T. and Jeary, T. 2007. Communicating the value of learning, $T \& D, 61(5): 80-84$. 
5. Chambers, B. and Pettman, J. 1986. Anti-racism: A Handbookfor Adult Educators, Australian Government Publishing Service, Canberra.

6. Clark, R.C. and Mayer, R.E. 2008. E-learning and the science of instruction: Proven guidelines for consumers and designers of multimedia learning. San Francisco, CA: Pfeiffer.

7. Crook, T.R., Todd, S.Y., Combs, J.G., Woehr, D.J. and Ketchen Jr, D.J. 2011. Does human capital matter? A meta-analysis of the relationship between human capital and firm performance, Journal of Applied Psychology, 96(3): 443-456.

8. Daley, B., Conceição, S., Mina, L., Altman, B., Baldor, M. and Brown, J. 2010, Integrative literature review: Concept mapping: A strategy to support the development of practice, research, and theory within human resource development, Human Resource Development Review, 9: 357-384.

9. Deem, R., Hillyard, S. and Reed, M. 2007. Knowledge, Higher Education, and the New Managerialism: The Changing Management of UK Universities. New York: Oxford University Press.

10. Demerouti, E., Bakker, A.J., Nachreiner, F. and Schaufeli, W.B. 2001. "The Job Demands-Resources Model of Burnout." Journal of Applied Psychology, 86(3): 499-512.

11. Entwistle, N. 2007. Research into student learning and teaching. In: Entwistle, N. and Tomlinson, P. (eds) Student Learning and University Teaching, (pp.1-18). Leicester, U.K.: Psychological Aspects of Education - Current Trends Monograph Series No. 4.

12. Freudenberg, B., Cameron, C. and Brimble, M. 2011. "The Importance of Self: Developing Students' Self-efficacy Through Work Integrated Learning.” The International Journal of Learning, 17(10): 479-96.

13. Gruber, T., Fub, S., Voss, R. and Glaser-Zikuda, 2010. Examining student satisfaction with higher education services using a new measurement tool. International Journal of Public Sector Management, 23: $105-123$.

14. Helyer, R. and D. Lee. 2014. "The Role of Work Experience in the Future Employability of Higher Education Graduates.” Higher Education Quarterly, 68(3): 348-72.

15. Horton, W. 2006. E-learning by design. San Francisco, CA: Pfeiffer.

16. Ketchen Jr, D.J., Crook, T.R., Todd, S.Y., Combs, J.G. and Woehr, D.J. 2017. Managing Human Capital, The Oxford Handbook of Strategy Implementation, pp. 283.

17. Klein, H.J., Wesson, M.J., Hollenbech, J.R. and Alge, B.J. 1999. "Goal Commitment and the Goal-Setting Process: Conceptual Clarification and Empirical Synthesis.” Journal of Applied Psychology, 84(6): 885-96.

18. Komarraju, M., Swanson, J. and Nadler, D. 2014. "Increased Career Self-efficacy Predicts College Students' Motivation, and Course and Major Satisfaction." Journal of Career Assessment, 22(3): 420-32.

19. Latham, G.P. and Locke, E.A. 2007. "New Developments in and Directions for Goal-Setting Research." European Psychologist, 12(4): 290-300.

20. Locke, E.A. and Latham, G.P. 2013. “Goal Setting Theory, 1990.” In New Developments in Goal Setting and Task Performance, edited by E.A. Locke and G.P. Latham, pp. 3-15. Hove: Routledge. 
21. Locke, E.A. and Latham, G.P. 1990. "Work Motivation and Satisfaction: Light at the End of the Tunnel." Psychological Science, 1(4): 240-46.

22. Lord, C.G. 1997. Social psychology. Fort Worth: Harcourt Brace College Publishers. Momentum Research Group. Retrieved November 03, 2004, from http://www.momentum researchgroup.com /glossary.php.

23. Maltz, L. Deblois, P. 2005. The EDUCAUSE Current Issues Committee. Top Ten IT Issues. EDUCAUSE Review, 40(1): 15-28.

24. Mason, G., Williams, G. and Cranmer, S. 2009. "Employability Skills Initiatives in Higher Education: What Effects Do They Have on Graduate Labour Market Outcomes?" Education Economics, 17 (1): 1-30.

25. Naismith, L., Lonsdale, P., Vavoula, G. and Sharples, M. 2004. NESTA future lab report 11: Literature review in mobile technologies and learning. Retrieved from. http://www2. futurelab.org.uk/resources/ documents/lit_reviews/Mobile_Review.pdf

26. Peters, K. 2007. m-learning: positioning educators for a mobile, connected future. International Review of Research in Open and Distance Learning, 8(2): 1-17.

27. Seijts, G.H. and Latham, G.P. 2011. "The Effect of Commitment to a Learning Goal, Self-efficacy, and the Interaction Between Learning Goal Difficulty and Commitment on Performance in a Business Simulation." Human Performance, 24(3): 189-204.

28. Smith, C. and Worsfold, K. 2015. "Unpacking the Learning-Work Nexus: 'Priming' as Lever for HighQuality Learning Outcomes in Work-Integrated Learning Curricula.” Studies in Higher Education, 40(1): $22-42$.

29. Smith, V. 2010. "Enhancing Employability: Human, Cultural, and Social Capital in an Era of Turbulent Unpredictability." Human Relations, 63(2): 279-303.

30. Star, C. and Hammer, S. 2008. Teaching generic skills: eroding the higher purpose of universities, or an opportunity for renewal? Oxford Review of Education, 34: 237-251.

31. Taylor, A.R. and Hooley, T. 2014. "Evaluating the Impact of Career Management Skills Module and Internship Programme Within a University Business School.” British Journal of Guidance \& Counselling, 42(5): 487-99.

32. Thune, T. and Støren, L.A. 2015. "Study and Labour Market Effects of Graduate Students' Interaction with Work Organisations During Education: A Cohort Study." Education and Training, 57(7): 702-22.

33. Tomlinson, M. 2012. "Graduate Employability: A Review of Conceptual and Empirical Themes." Higher Education Policy, 25: 407-31.

34. Tymon, A. 2013. “The Student Perspective on Employability.” Studies in Higher Education, 38(6): 841-56.

35. Wagner, N., Hassanein, K. and Head, M. 2008. Who is responsible for E-learning in Higher Education? A Stakeholders' Analysis. Educational Technology \& Society, 11(3): 26- 36.

36. Wilton, N. 2012. "The Impact of Work Placements on Skills Development and Labour Market Outcomes for Business and Management Graduates.” Studies in Higher Education, 37(5): 603-20. 
37. Yuen, S.C. and Yuen, P.K. 2008. Mobile learning. In: L.A. Tomei (Ed.), Encyclopedia of information technology curriculum integration. Hershey, PA: Idea Group.

38. Zhang, D., Zhou, L., Briggs, R. and Nunamaker, J. 2006. Instructional video in e-learning: Assessing the impact of interactive video on learning effectiveness. Information \& Management, 43(1): 15-27. 